\title{
INDEX
}

Abolition of Forced Labour Convention 292

Afghanistan

extremist groups in, 398-399

Air transport services

Warsaw Convention, jurisdiction under, 255

Antarctica

extra-territorial regime, 106-108

neutrality and demilitarisation, for,

129,142

participation in treaties, 282

Treaty, 106-108

Arbitration

participation in treaties, 282

Armed conflict

humanitarian law, 288

protection of civilians, Security

Council Resolution, 311-312

Asia-Pacific Economic Cooperation

Forum

annual meeting, 386

Task Force on Electronic Commerce, 380

Asia-Pacific Telecommunity participation in treaties, 298

Asian and Pacific Development Centre

Charter, amendments, 283

Asian-African Legal Consultative Committee

assessment of developments, 313-314

electronic commerce issues, 367-382.

See also Electronic commerce

establishment, 303

G-8 Summit, 308

General Assemble 54th session, report on, 318-321

International Criminal Court, confer-

ence on. See International Criminal Court
Japan, explanatory note from government of, 321-323

matters of common concern having legal implications, 305-306

matters referred to, 305

Measures to enforce the Fourth Geneva Convention in the Occupied

Palestinian Territory,

Conference of High Contracting

Parties, 309-310

UK International Meeting, 307-308

Member States, representatives of, 303

membership and organization, 304

Oslo Memorial Summit, 312

Palestinian Final Status Talks, 312

protection of civilians in armed

conflict, Security Council Resolu-

tion, 311-312

questions under consideration by International Law Commission, 304

sanctions against third parties, extraterritorial application of,

banana war, 317-318

executive orders, 315

Massachusetts Burma Law, 316-317

Presidential determinations, 315

reasons for imposition of, 314-315

State and Local Sanctions Acts, 315318

Sharm El-Sheikh Memorandum, 310313

special meeting, 306

States and property, jurisdictional immunity of,

commercial character of contract or transaction, 326-327

commercial transactions, concept of state enterprise, 328-329

constraint, measures of, 331-333 
employment contracts, 329-331 preliminary comments to General Assembly, 323-325

state, concept of, 325 subjects dealt with, 304 trade law matters, 306

UN Conference on Environment and

Development,

follow up to. See UN Conference on Environment and Development Secretariat Comments, 356-357

World Trade Organisation,

Dispute Settlement Understanding, review of, 362-363

Ministerial Conference, report on, 357-362, 364-366. See also World

Trade Organisation

Association of South East Asian Nations (ASEAN)

annual foreign ministers meeting 386

East Asian cooperation, 398

flexible engagement approach, 386

increased integration, attempts at, 386

North-east Asian summit talks, 398

Regional Forum statement on North

Korea, 412

Austria

neutrality, 128, 136

Bangladesh

India, border dispute, 387

Bhutan

refugees from, 411

Bibliography, 429-461

Book reviews, 423-427

Borders

Bangladesh-India, 387

East Timor-Indonesia, 387

Laos-Thailand, 387

Myanmar-Thailand, 387

North-South Korea maritime boundary, 388

Cambodia

Khmer Rouge leaders, genocide tribunal, 396-397

China, People's Republic of change of focus, 216
Chinese nationalism, vision of, 216

cross-strait dispute, 192-197

inter-State relations. See Inter-State relations

meeting between Dalai Lama and US president, protest at, 405

missile technology, 408

nation building, domestic programme of, 193

North Korean refugees, policy on, 411

one China principle, 192-193, 207

recognition and statehood, interrelationship of, 197-207

Republic of China, as successor government to, 191

return of Taiwan to, 193

Sino-US comprehensive agreement, 398

Taiwan,

sovereignty extended to, 191

threat to attack, 391

$\mathrm{UN}$, admission to, 194

unification policy, 197

World Trade Organization membership, bid to, 397-398

China, Republic of. See also Taiwan

cross-strait dispute, 192-197

cultural reconstruction, 196

de jure state, assertion of, 199

de jure statehood, no formal declaration of, 202, 207

derecognition, 198-199

economic determinants, [political

identity underpinned by, 217-218

national unification, policy of, 194-195

nationalism, policy of, 193

one China principle, 194-195, 207

political entity, designation as, 202

political identity, 218

statehood, recourse to notion of, 198199

successor government to, 191

Taiwan, nationalists retreating to, 192

UN, seat at, 193

World Trade Organisation, accession to, $218-219$

Climate change

Framework Convention, 285 
Comprehensive Nuclear Test Ban Treaty, 299

Convention for the Suppression of Unlawful Acts Against the Safety of Navigation, 17-19

Convention on Facilitation of International Maritime Traffic, 297

Convention on Psychotropic Substances, 294

Convention on the Nationality of Married Women, 286

Convention on the Physical Protection of Nuclear Material, 295

Convention on the Political Rights of Women, 286

Convention on the Rights of the Child Armed Conflict, involvement in, Optional Protocol, 287

Convention on the Rights of the Child Sale of Children, Child Prostitution and Child Pornography, Optional Protocol, 288

Crimes

international, participation in treaties 289-291

Cultural matters

participation in treaties, 282

Cultural property

participation in treaties, 282

Deep sea-bed

extra-territorial regime, $110-115$

general interest in regime for, 112-113

juridical nature of, 113

objective regime, 110-115

Demilitarisation

objective regimes, 128-130

Democratic governance

new international order, as cornerstone of, 207

rising notion of, 203, 205

Development participation in treaties, 283

Diplomatic and consular relations

Myanmar, UK national in, 389

North Korea-Italy, 389

Taiwan-Papua New Guinea, 390
Vatican, unofficial envoy in Hong

Kong, 389

Disarmament

law of, Indian perspective, 75

Discrimination (Employment and

Occupation) Convention, 292

Dispute settlement

participation in treaties, 283

\section{East Timor}

Indonesia, border dispute, 387

self-determination, 413-417

Timor Gap Treaty, state succession, 418

Eastern Europe

new states, recognition of, 203

Electronic commerce

Asia-Pacific Economic Cooperation

Forum Task Force, 380

certification authorities, 337-374

computer access, 369

data messages, communication of, 373

developing countries, impact on, 367370

digital signatures, 337-374

European Commission, work of, 379380

functional equivalence, 372

human resource development, 371

infrastructure-related difficulties, 369

international legal and policy frame-

work, fashioning, 380-382

legal and policy issues, 370

legal frameworks, adequacy of, 369

legislation, Philippines, 262-263

media or technology neutrality, 372

OECD, work of, 379

party autonomy, 372

security concerns, 370

UNCITRAL Model Law, 371-373

UNCTAD, work of, 378

World Intellectual Property

Organisation,

databases, protection of, 374

digital agenda, 375-376

domain names, work in, 375

E-business environment, 375

Internet Treaties, 374-375 
task of, 374

World Trade Organisation disciplines, 377-378

Environment

flora and fauna, 283

law of, Indian perspective, 75

marine pollution regimes, 121-125

pollution, 284-285

protection,

general interest in, 142-143

regimes, 121-128

trustees for, 101

Family

participation in treaties, 285

Finance

participation in treaties, 286

Fisheries

albacore tuna stocks, depletion of, 125

high seas, international control of, co-operation, role of regional arrangements, 138-139

competence, issue of, 138-139

conservation and management, general interest in, 118

driftnet fishing, 125-126

objective regime, 115-121

regional organisations or arrangements, incentive to participate in, 120-121

Straddling Stocks Agreement, 115121

third States, rights of, 116-117

Freedom of Association and Protection of the Right to Organise Convention, 292

\section{Greater East Asia}

new order for, 83

Health

participation in treaties, 286

Hong Kong

Vatican, unofficial envoy, 389

Human rights

equality before the law, 250-251

international level, implementation on, 74 law of, Indian perspective, 73-74

legislation, Indonesia, 234-235

life, right to, 231-233

Malaysian Human Rights Commission, 248-249

participation in treaties, $286=288$

India

ancient,

civilizations, 32

democracy, rudiments of, 35

diplomatic relations, $35-36$

force, non-use of, 38

foreign trade law, 37-38

humanitarian law, 38-39

imperialism, 40-42

kingship, 33-34

maritime adventures, 40

neutrality, 39-40

polity, 33

religious tolerance, 37

scope of, 32

shipping law, 37-38

sovereignty, 33-35

state system, 33-35

trade relations, 35

treaties, 36-37

welfare state, 35

Bangladesh-India border dispute, 387

caste system, 32

colonial era,

annexed territories, 54

armed conflict, humanitarian law, 64-

65

beginning of, 45

British Crown, paramountcy of, 52

British factories, 47

British rule, legality of, 47-50

British traders, protection of, 55

cruelty, 54

disaffection and hostility, 55

Doctrine of Lapse, 53

East India Companies, 46-47

expansionism, 47, 51-55

force, use of, 52-55

Indian state system, status of, 50-52

international law issues, 47

interventionism, 52-55

law of the sea, 55-57 
maladministration, 54

organized political bodies, dealing with, 51

promises, broken, 51

Subsidiary System, 53

treaties, 57-64

treaty obligations, enforcement of, 54

war, concept of, 64-65

foreign national, right to be treated with dignity, 231-233

history, European view of, 31

independence movement, 65-66

inter-State relations. See Inter-State relations

intergenerational equity, principle of, 229-231

International Court of Justice, objection to assumption of jurisdiction by, 223-227, 396

international law,

British rule, legality of, 47-50

colonial era, issues in, 47

contribution to, 68-76

Declaration on Friendly relations, 6970

disarmament, 75

environment, of, 75

human rights and self-determination, 73-74

international economic relations, equity in, $72-73$

law of the sea, 70-72

modern, 67

Nehruvian perspective of, 65-68

outer space, law of, 72

peace, promotion of, 67-68

survey of, 76

terrorism, legal controls of, 74

understanding of, 31

law of the sea, 55-57

medieval,

armed conflict, humanitarian law, 4445

civilization, 42

religious tolerance, $42-43$

scope of, 42

secularisation of state, 44

welfare state, $43-44$ modern era,

international law making, contribution to, 68-76

Nehruvian perspective of international law, 65-68

Mughal Empire, 50

natural resources, sovereignty over, 73

nuclear weapons, use of, 420

Pakistan, aerial incident with, 223-227, 396

Portuguese search for, 45-46

right to life, violation of, 231-233

sexual harassment, decision on, 228229

treaties,

ancient era, in, 36-37

authority to conclude, 60

capitulatory, 62-63

colonial era, in, 57-64

discriminatory clauses, with, 63-64

equal and unequal, 58-59

Indian ruler and European power,

between, 60

languages of, 60

personal, 59

Right of Passage case, 60-62

secularisation of law, 58

Indonesia

Aceh, insurgents in, 393-394

archipelagic sea lanes, 406

East Timor-Indonesia border dispute, 387

foreign relations, conduct of, 233

human rights legislation, 234-236

international crimes, adjudication of, 236

Irian Jaya, province of, 394

treaties, conclusion and ratification of, 235

US, military cooperation with, 407

Insurgents

Indonesia,

Aceh, 393-394

Irian Jaya, 394

Laos, 396

Philippines, 395

Sri Lanka, 395

Intellectual property 
participation in treaties, 288-289

Inter-State relations

Afghanistan, extremist groups in, 398399

China-India, 399

China-Israel, 399

China-Japan, 399

China-US, 400

China-Vatican, 400

East Asian cooperation, 398

Iran-US, 401

Japan-North Korea, 401

North Korea-Europe, 402

North Korea-Russia, 402

North Korea-US, 402-404

North-east Asian summit talks, 398

South Korea-Japan, 404

South Korea-US, 404

Sri Lanka-Israel, 405

Vietnam-US, 405

International Convention for the safety of Life at Sea

Protocol, 297

International Convention on Load Lines

Protocol, 297

International Convention on the Elimination of All Forms of Discrimination against Women, 228

Optional Protocol, 287

International Convention on the Protection of the Rights of All Migrant Workers and Members of Their Families, 287

International Covenant on Civil and Political Rights, 287

International Covenant on Economic, Social and Cultural Rights, 287

International Criminal Court ad hoc Committee on, 335

administration, 344

aggression, report on crime of, 345-347

composition of, 344

conference on establishment of, 334

criminal law principles, application of, 340-341

draft Statute, 334, 337

element of crimes, Working Group on, 344-345 establishment, 338

financing, 341

jurisdiction,

complementarity, 339

material, 338-339

trigger mechanism, 340

Preparatory Commission, 342-343, 348-350

Preparatory Committee, 335

ratification of statute, 341, 347-348

Review Conference, 341

Rules of Procedure and Evidence,

Working Group on, 343-344

Security Council, role of, 340

structure, 338

UN Diplomatic Conference, 336

International law

ancient civilizations, studies of, 76

areas of common concern, regulation of, 97

bearer-of-sovereignty debate, 91

bilateralism, critiques of, 100

changing demands of international society, not meeting, 100

classical, concerns of, 102

consensual nature, 97

Declaration on Friendly Relations, 6970

equality of states, development of concept, 89-90, 94

extra-territorial regimes,

Antarctic, for, 106-108

deep-sea bed, for, 110-115

high sea fishing, for, 115-121

outer space, for, 109-110

fundamental norms, expansion of, 141

Great Powers theory, 136-137

India, contribution of. See India

interests, range of, 102

law of the sea, 70-72

natural law theory, failure of, 90

normative approach, crisis in, 87

objective regimes,

academic literature, in, 98

alternative approach, as, 144

Antarctic, for, 106-108

areas of, 130-131

arguments supporting, 130 
concept of, 97

criteria for, 131-144

deep-sea bed, for, 110-115

defined content, 99

driftnet fishing, for, 125-126

environmental protection, 121-128

examples of, 105

extra-territorial, 106-121

general interest of international com-

munity, serving, 139-145

Great Powers theory, 136-137

high sea fishing, for, 115-121

institutional treaties distinguished, 134

intention to create, 131-132

justification, 144

legitimacy, no test of, 145

liberal approach, 137-138

marine pollution, for, 121-125

neutrality and demilitarisation, for,

128-130, 142

order, securing, 145

outer space, for, 109-110

ozone depletion, for, 127-128

role of, 98-103

state practice in support of, 105

States parties, competence or interest of, 135-139, 145

status of territory, regulation of, 133-

135

surrogate legislative role, 100

third parties, and, 134

treaties, as, 132

types of, 135

viability, 106

Vienna Convention, provisions of, 104-105

weak conceptual and juridical basis

for, 140

pacta tertiis rule, 99, 102

exceptions to, 103-131

Vienna Convention, narrow approach of, 104-105

prescriptive process, consent in, 99

scope of regulation, 101

traditional bilteral model, changes

undermining, 102

treaties, codification and development by, 103

principles underpinning, 104

universalist view, 91

wider range of subjects, 101

International representation

participation in treaties, 291

International trade

participation in treaties, 291

Iran

civil suits against foreign states, jurisdiction to hear, 237-238

inter-State relations. See Inter-State relations

Israel

inter-State relations. See Inter-State relations

Japan

constitutional regime, post-war, 87-88

cultural state, concept of, 88

democracy, rendition of, 82

emperor, status of, 88

foreign policy,

idealism and realism debate, 79

inter-war period, 80-87

post-war discourse, formulation of, 87-93

post-war theorists, 80

Hague Conventions, judicial decisions on, 238-239

inter-State relations. See Inter-State relations

international politics, theory of, 81,93

Japan-US cooperation in missile development, 406

Japan-US missile defence, 405

Manchurian Incident, 83

Meiji period, studies in history etc of, 82

nationalism, assessment of, 94

peace debate, 91-92

political thought, idealist and realist models, 80-87

renunciation of war, constitutional provision, 89

security treaty issue, $79-80$

Shanghai Incident, 239-241

socio-economic problems, 88 
South Korea, military cooperation with, 406

Judicial and administrative cooperation participation in treaties, 291-292

Kashmir

armed clashes, 417-418

autonomy, vote for, 418

Pakistan-US agreement, 417-418

Kazakhstan

North Korea jet fighter sale, 412

Korea. See also North Korea; South

Korea

cancer-causing defoliant, use of, 393

four-party talks, 392

inter-Korea talks, 392

maritime boundary, 388

North-South Summit Meeting, 393

Labour

participation in treaties, 292-203

Laos

Hmong insurgents in, 396

Laos-Thailand boundary dispute, 387

Macau

Chinese rule, reversion to, 388

Malaysia

foreign judgments, enforcement of, 247

foreign proceedings, stay of, 242-244

Human Rights Commission, 248-249

Spratly reeks, occupation of, 419

tort, place of, 245

UN Special Rapporteur, diplomatic immunity, 245-247

Marine pollution

rare and fragile ecosystems, protection and preservation of, 122

regimes for, 121-125

regional arrangements, 121-125

South East Pacific Convention, 123124

South Pacific Convention, 123

Mediterranean

Specially Protected Areas of Mediterranean Importance, 123

Migrant workers

Filipino, in Japan, 406
Military alliances

Japan-US, 406

Military cooperation

Indonesia-US, 407

Japan-South Korea, 406-407

Minimum Age Convention, 293

Missile technology

China, 408

North Korea, 407-408

Monetary matters

Asian cooperation, 409

Multilateral Investment Guarantee Agency

Convention establishing, 286

Museums

virtual exhibitions, 374

Myanmar

Myanmar-Thailand boundary dispute, 387

Thailand, sanctions on, 412

UK national in, denial of access to, 389

US sanctions against, 412

Narcotic drugs

participation in treaties, 293-294

Nationalism

Asian, 94

participation in treaties, 294

Natural resources

equitable utilization, 149

policies as to exploitation of, Sri

Lanka, 270-273

shared, ecosystem components, 187

Nepal

Bhutanese refugees, 411

citizenship, 249-250

equality before the law, 250-251

Neutrality

objective regimes, 128-130

New International Economic Order

call for, 73

law of the sea, and, 70

North Korea

ASEAN Regional Forum statement on, 412

inter-State relations. See Inter-State relations 
Italy, diplomatic relations with, 389

Kazakhstan-North Korea jet fighter sale, 412

missile technology, 407-408

North-South Korea maritime boundary, 388

nuclear energy,

facility, 410

Kumchangri, complex at, 410

North Korean-US agreement, implementation of, 409

uranium imports, denial of, 410

refugees from, 411

UN Command, talks with, 392

Nuclear energy

North Korea,

facility, 410

Kumchangri, complex at, 410

uranium imports, denial of, 410

North Korean-US agreement, implementation of, 409

Taiwan, radioactive wastes, 410

Nuclear material

participation in treaties, 294-295

Nuclear weapons

India, use by, 420

Oil pollution

participation in treaties, 284-285

Organization of the Islamic Conference

Summit Conference, 410-411

Outer space

extra-territorial regime, 109-110

law of, Indian perspective, 72

neutrality and demilitarisation, for, 129

participation in treaties, 295

Ozone layer

depletion, objective regimes, 127-128

Montreal Protocol, 127

participation in treaties, 284-285

Pakistan

India, aerial incident with, 223-227, 396

Kashmir, agreement on, 417-418

Particularly Sensitive Sea Area

development of, 122

practice, in, 123
Peace-making

changing approach to, 81

collective security theory, 92

Philippines

Communist rebels, talks with, 395

Electronic Commerce Act, 262-263

equal pay, 256

extradition treaty,

incorporation, doctrine of, 261-262

interpretation of, 254

food, international agreements, 266

foreign judgments, enforcement of, 260

foreign law, proof of, 257

industrial property treaties, 252-253

international agreements, 266

International Humanitarian Law Day, 267

Islamic insurgents in, 395

professional Regulation Commission

Modernization Act, 263-264

tax treaties, Most Favored Nation status, 251-252

trademarks and tradenames, protection of, 252-253

treaty provisions and municipal law, reconciliation of, 265

visiting force agreement, ratification, 258-259

Warsaw Convention, jurisdiction under, 255

World Trade Organization Trade-

Related Investment Measures, implementation of, 264-265

Piracy

ARF enforcement agencies, 27

armed robbery, definition, 19

arms used, 9

boarding ships, methods of, 9

cinema image, 4

coastal State, jurisdiction of, 21-23

combating, cooperation on, 411

Convention for the Suppression of Unlawful Acts Against the Safety of

Navigation, 17-19

cooperative instruments, development of, 24

cost of, 10

detecting, 7 
Draft Regional Agreement, 24

EEZ, in, 14-15

Guidelines for Regional Maritime Cooperation, 26

high seas, on, 14

hot pursuit, right of, 22

hot-spots, 8

IMB, role of, 27

inadequacy of definition, 28

increase in, 4-6

international definitions, $19-20$

iure gentium, 3

land, origins on, 5

large-scale, eradication of, 4

legal definition, 10-19

location of, 14-15

Malaysia and Indonesia, cooperation between, 25

military personnel, by, 13-14

Model Action Plan, 23

modern, extent and nature of, 7-10

number of incidents of, 7

obsolescent provisions, 4

ordinary meaning, 11

passengers and crew of hijacked ship,

by, 17

peace dividend, effect of, 6

place outside jurisdiction of state, on, 14-16

political, 12-13

private ends, for, 12-13

problems in dealing with, 21-23, 28-29

public service, by crew of ship on, 13-

14

recommendations for preventing and

suppressing, 23

regional initiatives against, 23-28

rise and fall and rise of, 4-6

scale of, 9

seizure of pirates, $20-21$

Singapore and Indonesia, direct communications between, 24

Tokyo Declaration, 23

Track One and Two bodies, 25-26

two ships rule, 17

unclaimed territory, in, 16

UNCLOS, definition in, 11

unilateral actions against, 27 universal jurisdiction, 3

vessels, theft of, 9-10

violence, acts of, 11-12

Political thought

E.H. Carr, work of, 85-87, 94

idealism, criticism of, 86-87

idealist and realist models, 80-87

ideology, increasing weight of, 81

Morgenthau, theories of, 84-85, 94]

Neo-Kantians, legal philosophy of, 84

realist international, 84

regionalist theory, 83-84

universalist normativity, perception of, 82

Wilsonianism, 81, 86

Pollution

intergenerational equity, principle of, 229-231

marine. See Marine pollution

no pollution harm principle, $149-150$

participation in treaties, 284

serious harm, obligation to prevent,

147, 159-160

serious injury, prevention of, 148-149

Trail Smelter case, 177

transfrontier harm, 149

US cases, 178-181

watercourses, of. See Watercourses, international

Privileges and immunities

participation in treaties, 295-296

Refugees

Bhutan, from, 411

North Korea, from, 411

participation in treaties, 296

Regional security

ASEAN Regional Forum statement on

North Korea, 412

Road traffic and transport

participation in treaties, 296

Russia

inter-State relations. See Inter-State relations

Sanctions

Kazakhstan-North Korea jet fighter sale, 412 
Myanmarese, 412

US, against Myanmar, 412

Sea

Indonesian archipelagic sea lanes, 406 participation in treaties, 296

Sea traffic and transport participation in treaties, 296-297

Self-determination core legitimacy, derivation of, 214 cross-Strait dispute, in, 209

East Timor, 413-417 enforcement of right, 213 internal, 214-217

justification for statehood, as, 208 nation, definition of, 210-213

national, principle of, 208

people, qualification as, 212-213

right of, 210

Taiwan question, 208-210

Sex discrimination

equal pay, 256

Sexual harassment

definition, 228

Singapore

forum non conveniens, decisions on, 267-269

international law matters, national laws on, 269

Single Convention on Narcotic Drugs 294

Social matters

participation in treaties, 297-298

South China Sea

draft regional code of conduct, 419

South East Pacific Convention

pollution control, 123-124

South Korea

inter-State relations. See Inter-State relations

Japan, military cooperation with, 406

South Pacific Convention

pollution control, 123

Sovereignty

ancient India, in, 33-35

bearer-of-sovereignty debate, 91

challenge to notion of, 102

extensive notions, allusions to, 103

limited view of, 102-103 natural resources, over, 73

Soviet Union

new states, recognition of, 203

Spratly reefs

Malaysian occupation, 419

Sri Lanka

arrest in violation of rights, 274

civil and commercial matters, mutual assistance in, 275

hostage taking, prevention of, 275

inter-State relations. See Inter-State relations

international law matters, national laws on, 274-276

maritime safety, 275-276

natural resources, policies as to exploitation of, 270-273

Tamil rebellion, 395

terrorism legislation, 274-275

State immunity

AALCC Working Group, comments of. See Asian-African Legal

Consultative Committee

State succession

Timor Gap Treaty, 418

Statehood

Chinese context, in, 191, 197-207

de jure, effect of, 201

Family of Nations, as preserve of, 204

formal declaration of, 201

inclusive approach, 204

international order created by, 209

interpretation of, 199-200

recognition, interrelationship with, 197207

self-determination as justification for, 208

traditional criteria, continuing validity of, 201

Statelessness

participation in treaties, 294

States

consent of people, governing with, 205

core legitimacy, derivation of, 214

creation, paradigm shift in, 206

de jure and de facto, 200-201

legal personality, 200

Montevideo Convention, 199, 206 
recognition,

collective process, not, 202

criteria for, 199

de jure state, qualification of, 199

doctrine of, 197-198

EU Guidelines, 203

new dynamic for, 203-204

non-democratic, 206

paradigm shift in, 206

purposes of, 198

statehood, interrelationship with, 197207

UN membership as birth certificate of, 202

Switzerland

permanent neutrality, 128

Taiwan

Chinese nationalism, declining importance of, 196

Chinese white paper, 391

de jure state, establishment of, 203, 207, 209

democratic reform, process of, 202

distinct people of, 212

economic development, 196

ethnic practices, 212

Filipino workers in, 406

imperial China, belonging to, 211

internal self-determination, 214-217

international status, dispute as to, 201

Japan, sovereignty ceded to, 211

mainland, relations with, 390, 392

nation, whether, 210-213

national self-determination, and, 208210

nationalists retreating to, 192

Papua New Guinea, diplomatic relations with, 390

political elite, 212

radioactive wastes, 410

sovereignty over, 191

possession of, 215-216

special administrative region, model

for, 197

state, whether, 191

succession to territory of, 199

unification guidelines, 389-390
US attitude to, 390-391

Telecommunications

participation in treaties, 298

Terrorism

international, legal controls of, 74

legislation, Sri Lanka, 274-275

Taleban, sanctions on, 419-420

US efforts to combat, 420

Thailand

Biological Diversity Convention, decision on, 276-279

Laos-Thailand boundary dispute, 387

Myanmar sanctions, 412

Myanmar-Thailand boundary dispute, 387

treaty-making power, 276

Treaties

general interest, facilitating, 143

institutional, 134

objective regimes, creation of, 132

participation in treaties, 298

Vienna Convention, 298

UN Conference on Environment and

Development

AALCC Secretariat Comments, 356357

activities implemented jointly, 353

adverse effects, 353

capacity building, 352

clean development mechanism, 354

compliance, 355-356

Conference of Parties, 350-351

emission trading, 355

forestry, 353

implementation, review of, 351-352

joint implementation, 355

land use, 353

protocol mechanism, 354

transfer of technologies, 352

UN Convention against Illicit Traffic in

Narcotic Drugs and Psychotropic

Substances, 294

UN Convention on the Law of the Sea cumulative achievements, 71 deep-sea bed regime, 110-115

negotiations, 71

participation, 296 
rare and fragile ecosystems, protection and preservation of, 122

Reciprocating States Regime, 114

states not party to, obligations of, 111112

United Nations

Declaration on Friendly relations, 6970

Nehru's view of, 68

Special Rapporteur, diplomatic immunity, 245-247

United States

Asia Pacific, foothold in, 194

Indonesia, military cooperation with, 407

inter-State relations. See Inter-State relations

Japan, missile cooperation with, 405406

Kashmir, agreement on, 417-418

North Korean-US nuclear energy agreement, implementation of, 409

Sino-US comprehensive agreement, 398

terrorism, efforts to combat, 420

Vatican

Hong Kong, unofficial envoy in, 389

inter-State relations. See Inter-State relations

Vietnam

inter-State relations. See Inter-State relations

Watercourses, international equitable utilization principle, academic views on, 162-164 appraisal, 186-188

breach, determining, 162

essence of, 151-156

interests, balancing, 152-156, 160

level of harm to be prevented, 166172

determining, 161

no pollution harm principle, relationship with, 156-162, 183-185

preventative measures, sharing, 160 relaxation of no pollution harm rule, arguments for, 162-166

relevance of, 159

water use entailing pollution, application to, 160, 162

Finland and Sweden, agreement between, 181

Gabcikovo-Nagymaros Project case, 182-186

no pollution harm principle, appraisal, 186-188

breach, determining, 162

equitable utilization principle, relationship with, 156-162, 183-185 essence of, 151-156

factual harm, prevention of, 151-152 priority, argument for, 183 relaxation by equitable utilization principle, 162-166

pollution of, activity producing, 160

appraisal, 186-188

appreciable harm, causing, 158, 166172,182

customary international law, 186

developing countries, by, 149

effects, treatment of, 168

government observations, 170-172

International Law Commission, discussions in, 157, 166-170

intra-generation and inter-generational equity, harmonizing, 188-189

judicial precedents, $177-182$

Montreal Rules, 156

obligation not to cause substantial injury, no derogation from, 178 preventive measures, degree of, 188 serious, 171

serious harm, obligation to prevent, 148

serious injury, prevention of, 148-149

state practice, $177-182$

US cases, 178-181

Watercourses Convention, position of, 173-177

transfrontier harm caused by, 150

unilateral diversion of water, 182-186 
upper riparian developing countries, protection of interests of, 164-166 use of waters, Helsinki Rules, 156 Watercourses Convention, position of, all appropriate measures, requiring, 174 compensation provisions, $175-176$ ex ante prevention of harm, 174 ex post remedial measure, 175-176 no pollution harm and equitable utilization principles, relationship between, 173 summary of, 176

Weapons participation in treaties, $299-300$

Women

violence against, 232

World Intellectual Property Organisation databases, protection of, 374 digital agenda, 375-376

domain names, work in, 375

E-business environment, 375

Internet Treaties, 374-375

Internet Treaties, 374-375

task of, 374

World Trade Organisation

core labour standards, inclusion on agenda, 365

Dispute Settlement Understanding, review of, 362 electronic commerce, disciplines affecting, 377-378

Ministerial Conference, Agriculture Working Group, 359

background, 357-358

developing countries, proposals articulated by, 366

fallout, 364

report on, 358-362

Working Group on Implementation and Rules, 359-360

Working Group on Market Access, 360

Working Group on Systemic Issues, 360

Working Group on the Singapore

Agenda and other issues, 360

Working Group on Trade and Labour Standards, 361

China's bid to membership, SinoJapanese talks, 397-398

Trade-Related Investment Measures, implementation of, 264-265

Worst Forms of Child Labour Convention, 293

Yugoslavia

new states, recognition of, 203 